\title{
A Critical Discourse Analysis of Soyinka's The Beatification of Area Boy
}

\author{
Dr. Francis Setonji YEDE \\ Department of English, Michael Otedola College of Primary Education, Lagos, Nigeria
}

\begin{abstract}
This paper is a Critical Discourse Analysis (CDA) of Soyinka's The Beatification of Area Boy. It critically interrogates the pattern of speech of the characters and its relation to how social power abuse and inequality are enacted, reproduced and resisted in the text. The analysis of the text unravels the perennial issues of corruption, poverty and societal imbalance which exemplify socio-political problems in Nigeria. There is also the reflection of the use of discursive features such as a variety of simple, compound and complex sentences to achieve pragmatic functions of social and interpersonal language use like interrogating issues, declaring personal motive and commenting on socio-political issues. These functions reflect communicative interactions in the realm of political, economic and cultural practices of Nigerians in the conversation situations analysed in the texts. Analysis of the text illustrates the view of the deprived people and shows that those who are in power are responsible for the use of language to create power and social inequality. CDA is therefore a useful tool to access salient information in texts and talk in order to checkmate power abuse and social inequality. The paper concludes that Soyinka's use of language in the text foregrounds social imbalance and disorientation of the people by the ruling class.
\end{abstract}

Keywords: Critical Discourse Analysis, Social Inequality, Ideology, Abuse of Political Power, Power Relation.

DOI: $10.7176 / \mathrm{JLLL} / 66-04$

Publication date:March $31^{\text {st }} 2020$

\section{INTRODUCTION}

The Beatification of Area Boy (Henceforth, The Beatification) one of Soyinka's plays was published in 1995. The play dwells on socio-economic barricades put up against the populace by the ruling class in Nigeria. The Beatification satirises and pin-points many issues, modes and characters identifiable in all sectors of the contemporary socio-cultural and economic landscape of Nigeria.

The main issues in The Beatification are poverty and class distinction perpetrated by the ruling class against the commoners through the instrument of social war. Many of the major characters in the plays are victims of the social, economic and political war perpetrated by the political class and visited on the hapless poor who constitute the majority of the Nigerian population. Soyinka reflects on the kind of war that government declares against the people through the execution or non execution of official policies. Such is the war that dislocates or disorientates millions of citizens with heart rending consequences.

MAMA PUT: Those that turned our fields of garden eggs and prize tomatoes into mush, pulp and putrid flesh - they plundered the livestock, uprooted yam and cassava and what did they plant in their place? The warm bodies of our loved ones. (The Beatification p. 21)

The above presents the image of destruction, wanton killing, chaos, insecurity, and the losses that are associated with war. Dehumanisation of humanity is painted through gory imagery. The effect on the psyche of an individual is pent-up-anger and dangerous emotional out-burst captured in the quotation above.

The Beatification is an illumination of the societal belief in ritual money making due to pervasive poverty situation of the citizens. To convince the readers, the play pinpoints the situation with the illustration of the human body parts believed to be the potent materials for money making rituals to illuminate the shared popular belief in ritual money making among the poor or the downtrodden in the socio-economic situation of the Nigerian society. It shows the society that has become dangerous, inhuman, apathetic and numb to the feeling and the plight of its citizens. (The Beatification p.15)

The Beatification as a literary works can be studied from the perspectives of content, form and style which can be understood by subjecting the text to careful Critical Discourse Analysis. The language used by Soyinka reflects the contemporary socio-political situations and problems in Nigeria and also, it serves as a tool for correction of defective socio-political practices.

\section{THEORETICAL FRAMEWORK OF THE STUDY}

Critical Discourse Analysis (henceforth CDA) "focuses on social problems and especially on the roles of discourse in the production and reproduction of power abuse or domination" (van Dijk, 2001:96). CDA sets up a relationship between language and power. In that sense, Wodak (2001) regards it as fundamentally concerned with analyzing opaque as well as transparent structural relationships of dominance, discrimination, power and control as manifested in language.

Fairclough (2001:125) defines CDA as "a form of critical social science geared towards illuminating the 
problems which people are confronted with in particular forms of social life, and to contributing resources which people may be able to draw upon in tackling and overcoming those problems." Van Dijk (2003) regards CDA "as a type of discourse analytical research that primarily studies the way social power abuse, dominance and inequality are enacted, reproduced, and resisted by text and talk in the social and political contexts." From Kazemian and Hashemi's (2014:10) point of view, "CDA is an interdisciplinary analytical viewpoint which looks into the relationship between power and discourse, and particularly it investigates the way in which authority, dominance and social inequality are constructed, sustained, reproduced and resisted in the discourse of written texts and spoken words."

It is expedient to explain what makes CDA critical. On a clear term, the word critical points out the practice of evaluating an object or situation in agreement with a system of rules, principles and values (Locke, 2004). Within CDA perspective, "critical" is not to be understood from the populist point of view of the word, e.g., being too critical or being negative about issues or personalities. Amoussou and Allagbe (2018:5) quoting Wodak (2001) claim that the concept of "critical" in this parlance means not taking things for granted but opening up complexity, challenging reductionism, dogmatism and dichotomies, being self-reflexive in one's research, and through these processes, making opaque structures of power relations and ideologies manifest. Suggesting and making available various ways of doing things can also be said to be aspect of being critical (Kendall, 2007). Rogers (2004:3) points out that within this framework of "critical discourse", the analyst's intention is to expose power relationships and express inequalities entrenched in texts and talks.

From the above definitions, Amoussou and Allagbe (2018:6) infer "that some key concepts Such as power, dominance, hegemony, ideology, discrimination, social order, reproduction, resistance, struggle, etc. figure prominently in any work of CDA."

\section{METHODS AND THEORETICAL FRAMEWORK OF THE STUDY}

CDA does not have its own specific methods different from other studies in social science and humanity. Rather, according to Fairclough (1989), each of the many existing approaches to language study -linguistics, sociolinguistics, pragmatics, cognitive psychology, conversation analysis, etc. - has something to contribute to CDA.

In practical terms, CDA adherents generally suggest taking recourse to linguistic theories in their analytical procedures. Taking cue from the above, Van Dijk (2001:97) submits that "explicit CDA needs a solid linguistic basis where linguistics is understood from a broad structural-functional direction." It should be noted that due to multidimensional nature and social semiotic approach of Systemic Functional Linguistics (SFL), it is a tool to be conveniently and practically applied to play a central role in critical discourse study. Widdowson (2004) in agreement with the above concurs that "CDA generally takes its descriptive and analytical procedures from Systemic Functional Grammar." Fairclough (2003:5) in praise of SFL says "it is a valuable resource for CDA and, indeed major contributions to CDA have developed out of SFL." It should be noted that CDA tackles the current social problems by opposing overriding ideological situations.

However a critical discourse analyst needs to note its multi-disciplinary nature and thus resort to a series of methods in the analysis of data. This means that the linguistic approach should be combined with historical, sociopolitical, sociological, anthropological, sociolinguistic, etc., analytical perspectives. In addition, Amoussou and Allagbe (2018:5) include analysis of the imprints of Transitivity, Mood and Modality, Vocabulary, Topicality, Presuppositions, Vagueness and Implicature as salient pathways to guide text analysis from CDA perspectives. Fairclough (1989: 26-27) identifies three analytical scopes for CDA which were adopted for the analysis of the text under investigation. The analytical dimensions adopted are:

- Description which is concerned with description of formal properties of the text.

- Interpretation is concerned with the relationship between text and interaction.

- Explanation is concerned with the relationship between interaction and social context.

The three stages indentified above are concerned with systematic analyses where each stage adopts different approaches. The first stage confines its scope to labeling the formal property of the text and views text as an entity. The second stage deals with the analysis of the cognitive progression of the participants and their exchanges. The third stage explains the connection between social events and social construction that influence the actions and reactions in the socio-political proceedings. This paper adopts the blended means of analytical procedures of CDA described above to analyse data. The text (The Beatification) was broken down into analytical sections tagged conversation situations to aid smooth CDA analysis.

Conversation Situation 1 (The Beatification p. 14-15)

1:

BARBER: You are the original doubting Thomas. But these things happen, that's all I can tell you. You see all those corpses with their vital organs missing - breasts in the case of women, the entire region of the vagina neatly scooped out. And sometimes just the pubic hair is shaved off for their devilish mixture. And pregnant ones with the foetus ripped out. Male corpses without their genitals or eyes. Sometimes they cut out the liver... making money. They take out 
2:

3:

the hunch, sometimes while the man self still dey alive....that one they picked up near Ita Faji cemetery had his birthday suit intact. He hadn't been skinned or anything like that. Even the eyes hadn't been touched. You would think it had something to do with the eyes - you know albinos don't like sunlight; maybe they drained the fluid from the eyes...

SANDA: Look, I've told you I don't want to hear all that kind of talk on an empty stomach. How soon will that Konkere be ready, mama put?

Mama Put: Any time you people can take your minds off the satanic work of these get-richquick swine. (The Beatification p. 15)

The conversation above is indicative of ritual money making activities in the contemporary Nigerian environment. It presents a pitiable and disoriented people suffering from bad governance and poverty - a people swimming in superstitions and constantly looking for alternative means to alleviate their poverty. This preoccupation develops in the attitudes and thinking patterns of the characters like Barber, Sanda, Mama Put and co. These characters discuss, through different opinions, their views and opinions on the phenomenon of the materialistic tendencies of the contemporary society and its diabolic consequences. The pervasive poverty in the society has led to desperation and belief in ritual money making. Thus, the belief that human body parts and vital organs like breasts of women, the entire region of the vagina, the pubic hair, pregnant women foetus, male corpses' genitals or eyes, cut out liver, the hunch-back, etc are potent materials for ritual money purposes has led to abduction, displacement and harassment of the common people and creation of life of perpetual fear and bondage. The Beatification reflects and condemns the present socio-political and religious atmosphere where preaching positive and developmental messages is replaced by entrenchment of negative sense of voodoo and fetish numbojumbo and the tendencies to use such to harass, defraud and disorientate the populace.

The utterance in speech 1 performs declarative function. This speech is a declaration of the speaker's belief in ritual money making. To convince the listeners, the speaker utilises the means of MCBs by loading the speech with the illustration of the human body parts believed to be the potent materials for money making rituals. The mention of such body parts as 'breasts', 'vagina', 'pubic hair', 'foetus', 'genital', 'the liver', 'the hunch' etc illuminates the shared popular belief in ritual money making among the poor or the downtrodden in the situation and the context of discussion. The use of the expressions containing the verbal particles such as 'neatly scooped out', 'shaved off', 'ripped out', 'cut out', 'take out', 'skinned', 'touched' etc are used by the speaker to show the deliberate and mindless actions of the ritual killers when dealing with their victims.

In speech 1, it is presumed that people get involved in all kinds of evil practices to acquire wealth. It is also inferred that Nigerians are bedevilled with poverty and thus, people will go all the ways to rid themselves of their state of poverty.

It is inferred that poverty is prevalent in Nigeria and almost everybody hate their poverty ridden situations. Characters in the conversation situation above desire a change in status and good living conditions. Hence, they result to money making ritual (a popular African belief and practice to acquire sudden wealth and overnight fame). This indicates contemporary socio-cultural beliefs and practices.

\section{Conversation situation 2 (The Beatification p. 98)}

1:

CHIEF KINGBOLI (rounds on MISEYI's father): You were in the know. You planned to humiliate me in public. You've never forgotten that oil contract you lost to my company.

2: MILITARY GOVERNOR (panicky): No, not here. Not in public.

3: $\quad$ CHIEF KINGBOLI: Why not? Because you backed him in cabinet? I knew you had an interest in his firm but I won the contract anyway. He's never forgiven or forgotten, neither had you. So you both plotted to inflict this disgrace on my family?

4:

MILITARY GOVERNOR: S-sh! Stop it! Let's go to my residence and sort this out. Let's all keep a cool head.

5: $\quad$ CHIEF KINGBOLI: Just remember I have friends and partners among your superiors!

The conversation above is indicative of activities of the corrupt politicians, their collaborators and the effect of their activities on the people in the contemporary Nigerian environment. Their activities are perpetrated through award of oil contract, shady deals, official backing of private business enterprises by highly placed government officials and friends and, subversion of government policies to build up personal business empires.

This preoccupation develops in the actions, and the dialogue of the characters like Chief Kingboli, Miseyi's Father and Military Governor. These characters are typical Nigerian economic saboteurs who appropriate the available collective natural resources for personal benefit in a selfish manner. This phenomenon is known in Nigeria as resource control. The people in power have to deal decisively with the other similar interest groups through highly placed government officials and friends who harass and stamp out other competing businesses out of existence. This causes tension, resentment and disenchantment that spiraled into the birth of socio-political menace like militancy, assassination and all forms of shady business deals in the contemporary Nigerian sociopolitical landscape.

speech 1 is made up of three simple sentences. They all perform declarative functions. They are used to reveal 
basic information known only to the three interlocutors in the conversation situation under analysis. Additionally, the revealed information can be said to be the personal belief of the interlocutor in speech 1 . This personal belief is based on the shared belief in the business world that nobody is to be trusted. One could have expected the two parties, to be on the leveled playing ground with each other, considering the fact that their children are about to go into marital relationship. Marriage serves as an umbilical cord between two families involved but the reverse is the situation presented by the sentence.

However, contrary to the notion of trust, amicable relationship, protection and family-like relationship expected of the two families, there are an unbelievable cat and dog and highly suspicious relationship that would have prompted one to question the reason of the two men giving out the hands of their children in marriage in the first place. The implicature of the second sentence of the speech is captured in the disagreement that is shown by the parties due to clash of business interest. The third sentence in the speech 1 of the conversation situation reveals the ember of suspicion, cat and dog life, make-belief marriage union, selfishness and haughty attitude of the businessmen and women in the murky business world. Their selfish attitude is shown in match-making and trade - off of their children in make-belief marriages to further establish or enlarge their business empires.

speech 2 is made up of two negative de-verbilised sentences. Here, we have the three negation items in the two grammatical constructions used separately to express caution and to instill reasoning in the conversation patterns of the two interlocutors. Here, we can infer that the subject of discussion has the undertone of secrecy an issue only to be known to the initiate of the murky waters of the business world. The first negation, "No" in the first sentence is to cut out the flow of the conversation. The second negation "not" and the adverbial "now" are used to indicate that the environment is not appropriate for the kind of discussion or the revelation to be embarked upon. The third negation "not" and the prepositional phrase "in public" which function as adverbial of place are used to point out that the issue at hand is a classified issue only to be tackled in an appropriate place-in the grove of the shady business world.

The implication is that business dealings are highly categorised and should be discussed in relation to the dictates of the situation. Clean business are to be discussed in public, while shady or top level businesses like oil contract and road construction, contract involving huge sum of money and whose licenses can be sold or resold are classified and should be kept out of the hearing of the common citizens. The ordinary citizen's social security and collective wealth are being siphoned and traded off to the gains of the privileged and highly placed citizens every day. This further estranged relationship between the rich and the poor in Nigeria.

The conversation in speech 3 and 5 shows that the private firms and businesses are owned by public servants like governors, ministers, senators and even the president who use their privileged positions to curry juicy contracts involving huge amount of money to their cronies or front men. The second sentence in speech 3 declares the backing and the interest of the political office holders and highly placed public servants in the private businesses. The sentence in speech 3 is highly revealing. It contains the lexicons "friends", "partners" and "superiors" which are pointers to the supporters and the sponsors of the private business interests across the country. The implicature of this sentence reveals that the backing and the interest of the selfish and the corrupt superior public officers always ensure that private business firms thrive at the expense of the publicly owned government business firms in Nigeria

\section{Conversation situation 2 (The Beatification p. 98)}

The POLICEMAN sees possible assistance in a man in security uniform and runs towards him with his captive.

1:

2:

3:

4:

5:

6:

7:

8:

9:

10:
POLICEMAN: Can you help, sir? Is there somewhere we can keep this man away from the crowd? They're determined to lynch him, although, why I should bother...

SANDA: What's the matter?

POLICEMAN: Missing genitals.

SANDA (groans): Oh, not again!

Shouts of 'Hand him over!' 'Let's roast him here before he roasts in hell.' They don't deserve police protection.' 'Tyre done ready, kerosene dey plenty."

SANDA: Stand by, Area Two-One. Send Boyko for some of ours. (To the POLICEMAN.) Which of them claims to be the victim?

VICTIM (steps forward): It's me, brother. He touched me, and it was gone.

SANDA: You are sure.

VICTIM: Am I sure? Don't I know what I left home with? And now there's absolutely nothing there. Nothing. He touched me and I felt it disappear. (Starts crying.)

POLICEMAN: Stop crying like a child. Stand up and behave like a man.

VICTIM: Behave like a man? Like a man? But that's the core of my problem. How do you expect me to behave like a man without it?

The conversation above is about ritual money making activities and the state of insecurity in the contemporary Nigerian environment. It presents a disoriented people suffering from bad governance and all sorts of superstition. This is manifest in the attitudes and thinking patterns of the characters like Policeman, Sanda, and victim. These 
characters' discourse illustrate the state of insecurity and lack of trust that always lead to accusation and counter accusation which has turned the Nigerian contemporary society to an extremely dangerous place to live on the Earth. The stifling poverty in the society, lack of social welfare and lack of effective state security outfit from Government to mitigate the unfavourable and the undesirables has led to desperation and belief in ritual money making. Also, the belief that human body parts and vital organs are potent materials for ritual money purposes has led to abduction of both the young and the old without traces and, creation of life of perpetual fear and bondage. The Beatification reflects on the present socio-political atmosphere in Nigeria where Government has failed in its responsibility to secure lives and properties of the citizens and thereby has left a wider gap for all forms of insurgencies and desperations that has spiraled into pointing accusing fingers in all directions and thereby disorientating the populace.

The utterance in speech 1 performs interrogative and declarative functions. The semantic function of the auxiliary "can" and the lexical verb "help" is to seek support from a man in uniform. Uniform signifies a sense of collective responsibility (security) and comradeship among security personnel. The second sentence in the speech also seeks protection for a victim of public anger and molestation. The two sentences in this speech indicate a sense of duty on the part of a public security figure that is almost overwhelmed by the prevailing situation. His frustration and detachment is intoned in the third sentence of the speech. The word "lynch" shows the intention of the crowd, which is bent on carrying out an extra-judicial-act that could result in killing an innocent citizen. The crowd is unruly and proving too much to handle for a single policeman. Such helpless situations abound in real life situations depicted in the conversation situation under analysis where policemen are ill-prepared, ill-equipped and also are posted to the unfamiliar terrains. The clause "although, why I should bother..."at the tail end of speech 1 uses the subordinator "although" to indicate an ambience of reluctance in the sense of duty of the policeman in the conversation situation. An inference drawn from this situation provides an outlook into why police and other security personnel go about their duties in a shoddy and lacklustre manner, especially, in Nigeria.

In speech 2, there is a graphological sign (?) attached to sentence and this makes it interrogative. It is used to probe the situation. This is typical of security personnel. They use questioning and interrogation to get to the root of knotty issues. In Africa, cultural and moral expectations demand that one should familiarise oneself with situations and issues before one dabbles into them.

Speech 3 and 4 are made up of de-verbalised sentences. speech 3 utilises a noun phrase "missing genitals" which provides an answer to the question in speech 2 . The noun phrase is structured towards giving a quick answer to the desperate situation at hand. It is also meant to create the ground for mutual contextual belief in money ritual characterised by unending sights of corpses without vital organs or body parts. It is linked to the claim of common cases of whipping up public sentiment about loss of vital body parts like sex organs, breast etc. and sentimental plea for their restoration.

The sentence in speech 4 is made up of verb-less construction though not entirely without element of negation (not) that is usually associated with verbs. It has an exclamatory indicator "Oh!" This makes the linguistic construction exclamatory. It is used to express surprise and disappointment. The negation "not "and the adverb "again" show that the issue of missing genital is a recurrent public issue. The exclamatory construction in the move also shows a sense of annoyance at total neglect of important issues by the people in authority. The puzzling issue about such recurring cases, therefore, is that no thorough investigation has been done and no basic conclusion about them has been drawn with verifiable evidence. It has become an anathema; a pain in the neck.

The conversation situation also displays an apt use of euphemism. Euphemism is used here to showcase cultural practices in the conversation situation under discussion. There is mutual contextual belief among the peoples of most cultures in Africa and in the world generally to discuss certain issues with couched explicitness and reverence. Prominent among such issues is the one that has to do with sexual habits and the organs involved. The pronoun "it" in speeches 6,8 and 9 is used inexplicitly to refer to the "missing genital." This is to show that certain body parts are to be discussed with couched explicitness. The use of the pronoun "it" in speeches 6,8 and 9 is also used anaphorically to link the noun phrase "missing genital" mentioned in speech 3.This makes the discourse smooth and coherent.

\section{Conversation situation 6 (The Beatification p. 98)}

Move 1: $\quad$ MISEYI: I wish I could be struck blind, suddenly, no, even before now. Or that my feet had taken me any other way but this.

Move 2: $\quad$ SANDA: (sadly). I can see your mind has not kept pace with the rest of you - that's a great pity. Move 3: $\quad$ MISEYI: (heatedly). And your mind has stood still, Sanda! Still, still, stagnant. You are still the way you talked! The eternal student at heart. People grow. They develop. You ...you ... Christ, it makes one weep inside to look at you! Did you abandon your degree programme, one year to graduation - for this? A megadi uniform for what should have been ...

Move 4: $\quad$ SANDA: ... an academic gown? (Laughs.) Now who is out of touch with change? Me or you? Do you know how many hundreds of PhDs are roaming the streets, jobless? Me, I have a fulltime job. And even compared to those with jobs - my take-home pay is twice theirs any week. 
Move 5:

And when I make up my mind and decide to earn good tips, I can take home six times that pay. MISEYI: And you're proud of that? You wear that megadi uniform, hold the door open for people ...

The conversation situation presents a decadent educational system in Nigeria. It negates the popular practice of utilitarian educational system that produces job creators, problem solvers, solution providers, adventurists and dynamic realist graduates in the advanced world. Sanda and Miseyi comment on the present educational system which is predicated upon the philosophy of idealism rather than on the philosophy of realism. Lack of educational system with realist's mindset of utilitarian and entrepreneurship skills has created unskilled graduates who cannot create job, provide solution to societal problems and create dynamic environment. This phenomenon is known in Nigeria as production of half-baked graduates. This has caused resentment and disenchantment among the scores of jobless graduates and as a result, the birth of socio-political menace like militancy, armed robbery and all forms of cyber-crimes in the contemporary Nigerian socio-political landscape.

This conversation situation projects a Nigerian society that looks down upon a graduate who wishes to be independent minded by taking up a job, profession or pursue a line of action below the expectation nursed by his society. The shared popular belief in the ideology of white collar job, sudden achievement or upward social mobility associated with a university degree is expressed in the use of noun phrases (NP) "a megadi uniform" and the NP filler "an academic gown" at the end of speech 3 and at the beginning of speech 4 in this conversation situation.

The ideological undertone expressed by the two noun phrases is significant. The noun phrase 'academic gown' symbolises the belief in our society that academic achievement or possession of higher certificates brings financial freedom, upward social mobility and access to white collar or fat salaried jobs. Meanwhile the noun phrase "a megadi uniform" is a symbol of failure. It is a sign of servitude and societal scorn: a necessary evil that can only be accommodated with a mixed feeling.

A 'megadi' is a Nigeria version of security hireling engaged to secure or provide security expertise for private or public outfits. In this situation or in a larger socio-cultural situation, it will include all form of domestic service providers who dispense such menial labour as cooking, washing, ironing of cloths, cleaning of the environment, etc. As important as their jobs are to their masters, they are still kept at bay - they are made to sleep in sentry posts or in boy's quarters located at the less-conspicuous sections of their masters' compounds. They cultivate less or no respect from the society.

The hopeless situation of the average Nigerian graduate, their lack of innovation and lack of entrepreneurship skill are reeled out in speech 4. This situation is crafted in the interrogative statement "Do you know how many hundreds of PhDs are roaming the streets, jobless". Here the owners of $\mathrm{PhD}$ are de-emphasised. Instead, the academic title 'PhD' is emphasised and personified as "the tramp," "the undesirable," "the jobless roaming the street looking for job." This is a gory picture of dehumanisation, facelessness, ignominy, dishonour and rape of the utilitarian educational culture and practice that our society once held with respect and honour. It calls for one to reflect on the value of PhD holders, what they do and how they are perceived in the Western societies.

\section{Conclusion}

CDA's main objective is to represent the influential role that language plays in emanation of power and legitimitisation of social inequalities. The analyses of the selected conversation situations in the text show the dominant ideology of tyranny and oppression of the less privileged by the powerful people who control all wealth yielding resources. It is noted that Hegemony and social inequality are foisted on the people and actualized through selective language use by the people in power (Yede, 2018:143). CDA analytical procedures, employed by this study reflected the hidden power relations and ideological processes in the conversations of the characters in The Beatification. This is pointed out through the analyses of the use of language. CDA foregrounds the view of the deprived people and analyses language critically to show that those who are in power are responsible for social inequalities. The responsibility of the playwright in a poverty-ridden and complex socio-political environment like Nigeria is significant because his works expose the arrogant and repressive tendencies of the rulers. Soyinka plays manifest the commitment of the artist as a critic of social misdemeanors. The uniqueness of this play is how Soyinka has used language to highlight distortion of the society and disorientation of the people by the ruling class.

\section{REFERENCES}

Amoussou \& Allagbe (2018), Principles, Theories and Approaches to Critical Discourse Analysis. International Journal on Studies in English Language and Literature (IJSELL), vol 6, no. 1, 2018, pp. 11-18. doi:http://dx.doi.org/10.20431/2347-3134.0601002.

Fairclough, N. (1995). Critical Discourse Analysis: the critical study of language. London: Longman.

Fairclough, N. (2001). Critical discourse analysis as a method in social scientific research. In R. Wodak \& M. Meyer (eds.), Methods of Critical Discourse Analysis (pp. 121-138). London: Sage.

Fairclough, N. (2003). Analysing Discourse: Textual Analysis for social research. New York: Routledge. 
Fairclough, N. (1989). Language and power. London: Longman.

Fairclough, N. (1992). Discourse and social change. London: Polity Press.

Fairclough, N. (1995). Critical discourse analysis. London: Longman.

Jahedi, M., Abdullah, F. S. \& Mukundan, J. (2014). An Overview of Focal Approaches of Critical Discourse Analysis. International Journal of Education \& Literacy Studies, 2 (4), 28-35.

Kazemian, B. \& Hashemi, S. (2014). Critical Discourse Analysis of Barack Obama ${ }^{\text {ee }} 2012$ Speeches: Views from SFL and Rhetoric. Theory and Practice in Language Studies, 4 (6), 1178-1187.

Kendall, G. (2007). What is CDA? In Ruth Wodak (Ed) Forum: Qualitative Social Research, 8 (2). Retrieved from http://nbn-resolving.de/wrn:nbn:de:0114-fqs 0702297, on August, 9th, 2016.

Locke, T. (2004). Critical Discourse Analysis. London \& New York: Continuum International Publishing Group.

Meyer, M. (2001). Between theory, method, and politics: positioning of the approaches to CDA. In R. Wodak \& M. Meyer (eds.), Methods of Critical Discourse Analysis (pp. 14-31). London: Sage.

Rahimi, F. \& Riasati, M. J. (2011). Critical Discourse Analysis: Scrutinizing Ideologically-Driven Discourses. International Journal of Humanities and Social Science, 1 (16), 107-112.

Rogers, R. (2004). An Introduction to Critical Discourse Analysis in Education. London: Lawrence Erlbaum Associates, Inc.

Soyinka, W. (1995). The Beatification of Area Boy. Ibadan: Spectrum Books Limited.

Van Dijk, T., A.(2001). Multidisciplinary Critical Discourse Analysis: A plea for diversity. In R.Wodak \& M. Meyer (eds.), Methods of Critical Discourse Analysis (pp. 95-120). London: Sage.

Van Dijk, T., A. (2003). Critical Discourse Analysis. In D. Schiffrin, D. Tannen, \& H. E. Hamilton (ed), The Handbook of discourse analysis (pp. 352-371). Maiden, MA: Blackwell.

Widdowson, H. G. (2004). Critical discourse analysis. In H. G. Widdowson (ed). Text, Context, Pretext: Critical Issues in Discourse Analysis (pp. 89-111). Malden, MA: Blackwell Publishing Ltd.

Wodak, R. (2001). What Critical Discourse Analysis is about-a summary of its history, important concepts and its developments. In R. Wodak \& M. Meyer (eds.), Methods of Critical Discourse Analysis (pp. 1-13). London: Sage.

Wodak, R. (2009). Critical discourse analysis: history, agenda, theory, and methodology. In R. Wodak \& Meyer (eds), Methods of Critical Disocurse Analysis (pp. 1-33) 2nd edition London: Sage.

Wodak, R. \& Meyer, M. (2001). Methods of Critical Discourse Analysis. London: Sage.

Yede, F.S.(2018).A Stylo-Pragmatic Analysis of Soyinka's The Beatification of Area Boy and Alapata Apata. Unpublished PhD Thesis, Olabisi Onabanjo University, Ago-Iwoye. 